\title{
A-rare-case of h-type tracheoesophageal fistula treated with slide tracheoplasty
}

\author{
Ulaş KUMBASAR ${ }^{\mathbf{1}}$ (ID) \\ Serkan $\operatorname{UYSAL}^{1}$ (ID) \\ Rıza Önder \\ GÜNAYDIN ${ }^{2}(I D)$ \\ Rıza DOĞAN ${ }^{1}(I D)$
}

${ }^{1}$ Department of Thoracic Surgery, Hacettepe University Faculty of Medicine, Ankara, Turkey

${ }^{1}$ Hacettepe Üniversitesi Tıp Fakültesi, Göğüs Cerrahisi Anabilim Dalı, Ankara, Türkiye

${ }^{2}$ Department of Otorhinolaryngology, Hacettepe University Faculty of Medicine, Ankara, Turkey

${ }^{2}$ Hacettepe Üniversitesi Tıp Fakültesi, Kulak Burun Boğaz Anabilim Dalı, Ankara, Türkiye
Cite this article as: Kumbasar U, Uysal S, Günaydın $R O ̈$, Doğan R. A-rare-case of $h$-type tracheoesophageal fistula treated with slide tracheoplasty. Tuberk Toraks 2020;68(4):449-452.

\section{Yazışma Adresi (Address for Correspondence)}

\section{Dr. Serkan UYSAL}

Hacettepe Üniversitesi Tıp Fakültesi Hastanesi, Göğüs Cerrahisi Anabilim Dalı,

ANKARA - TÜRKIYE

e-mail: serkan.uysal@hacettepe.edu.tr

\footnotetext{
CCopyright 2020 by Tuberculosis and Thorax.
}

Available on-line at www.tuberktoraks.org.com

\begin{abstract}
A-rare-case of h-type tracheoesophageal fistula treated with slide tracheoplasty

Tracheoesophageal fistulas (TEFs) are abnormal connections between the esophagus and tra-chea and are associated with atresia of the esophagus in most cases. Herein, we present a case of H-type TEF in a young woman which is successfully treated with slide tracheoplasty technique.

Key words: H-type tracheoesophageal fistula; slide tracheoplasty; surgery

ÖZ

Sliding trakeoplasti ile tedavi edilen nadir bir olgu: h-tipi trakeoözefageal fistül

Trakeoözofageal fistüller (TÖF) özofagus ve trakea arasındaki anormal bağlantılardır ve çoğu durumda yemek borusunun atrezisi ile ilişkilidir. Burada slide trakeoplasti tekniği ile başarılı bir şekilde tedavi edilen genç bir kadında $H$ tipi TÖF olgusu sunulmaktadır.
\end{abstract}

Anahtar kelimeler: H tipi trakeaözofageal fistül; sliding trakeoplasti; cerrahi

\section{INTRODUCTION}

Tracheoesophageal fistulas (TEFs) are abnormal connections between the esophagus and trachea and are associated with atresia of the esophagus in most cases. Diagnosis is not challenging in the neonatal period due to the typical symptoms such as choking following food intake, coughing and pneumonia (1). However, a rare subgroup of TEFs, termed $\mathrm{H}$-type fistulas, are not associated with esophageal atresia, produce minimal symptoms 


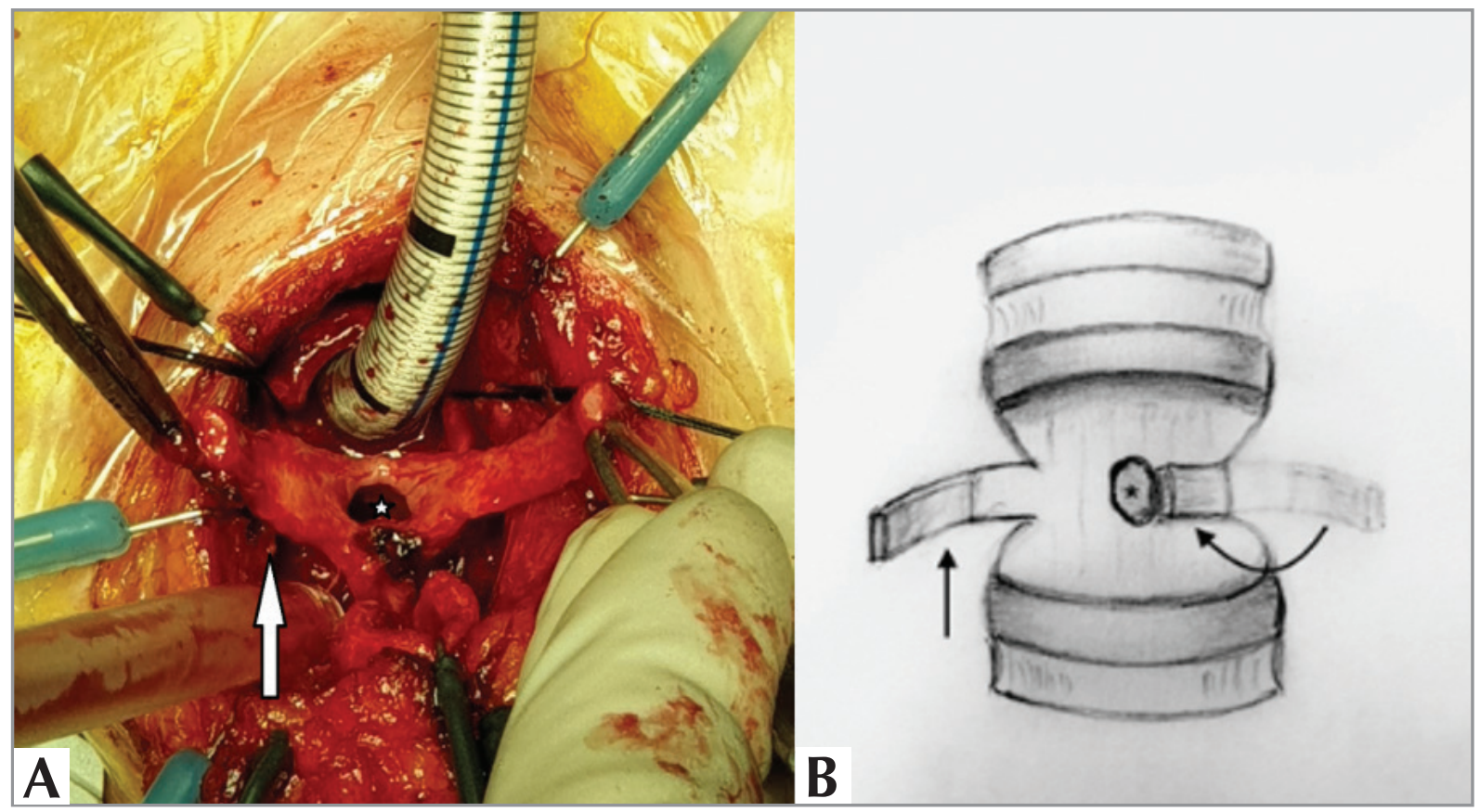

Figure 1. A. Tracheoesophageal fistula operation view B. Tracheoesophageal fistula and cartilage portion drawing.

and thus, usually diagnosed during adulthood (2). Herein, we present a case of H-type TEF in a young woman which is successfully treated with slide tracheoplasty technique.

\section{Presentation of Case}

A 36-year-old female, non-smoker, presented to our institution with diagnosis of TEF. She had a history of persistent cough since childhood, sometimes initiated after swallowing liquids, and had recurrent chest infections. She was followed-up with the diagnosis of asthma for several years. She was diagnosed with TEF in another hospital 6 months ago and undergone endoscopic esophageal clipping. However, her symptoms recur shortly and she admitted to our institute. Her physical examination and chest x-ray was unremarkable. Esophagoscopy showed. Examination with a direct laryngoscopy showed a fistula in the posterior wall of the trachea.

A low collar cervical incision was performed to access the fistula. Anterior wall of the trachea is freed from surrounding tissues down to the carina. Flexible bronchoscopy through the endotracheal tube was performed to confirm the exact location of the fistula. Then the trachea is divided both from the superior and inferior borders of the fistula, leaving the small portion of the posterior trachea attached to the fistula tract (Figure 1). The superior and inferior tracheal segments are freed from the esophagus. The cartilage portion of the trachea that remains attached to the fistula tract is trimmed, inverted and folded on to the esophageal portion of the fistula tract. Interrupted vycril sutures are used for closure of the fistula with the enforcement of the folded cartilages. Following the closure of the defect the two segments of the trachea are trimmed to achieve better approximation and anostomosed obliquely (Figure 2). Left sided hyoid muscle is freed and transferred between the trachea and esophagus for additional reinforcement to minimize the risk of long-term recurrence. The patient remained nasally intubated in the intensive care unit for one day and extubated on postoperative day one. Bed side direct laryngoscopy was performed to check the anastomosis and the vocal cord movements. Postoperative course was uneventful. Patient started oral fluids on the $10^{\text {th }}$ postoperative day after confirming the integrity of the anostomosis with computed tomography (CT) scan and discharged home on $13^{\text {th }}$ postoperative day.

\section{DISCUSSION}

Congenital H-type TEFs presenting in adults are rare and has only been documented in the literature as sporadic case reports. The first surgical repair was reported by Mathey in 1954 (3). Typical presenting 


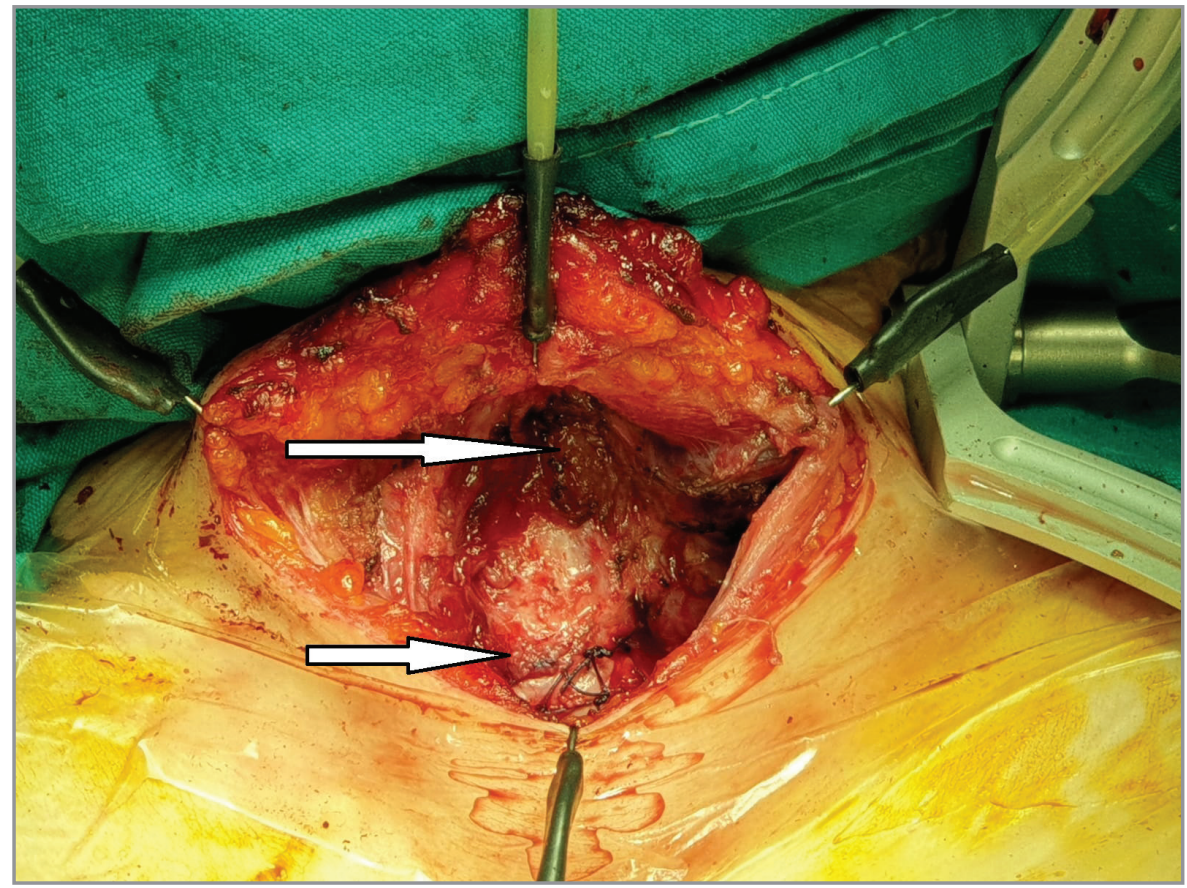

Figure 2. After the anastomosis - left side hyoid muscle is used as a flap.

symptoms are chronic cough and recurrent pulmonary infections. Although coughing spells when swallowing liquids are pathognomic for this condition, diagnosis might be delayed in some patients.

Several imaging methods can be used in the diagnosis of TEF. Thin-section chest CT and three-dimensional reconstruction is helpful for both showing the exact location of the fistula and the potentially irreversible damage of the lung parenchyma. Bronchoscopy and esophagoscopy are considered to be the main methods to diagnose TEF. However, identification of smaller fistulas can be challenging in some cases. Likewise, fistulas located in the upper $3^{\text {rd }}$ and on the anterior wall may be missed on esophagoscopy $(1,4)$.

Treatment of congenital $\mathrm{H}$-type TEF is surgical closure of the fistula. Although interventional treatment strategies such as stent implantation or endoscopic clipping have been proposed, their results are not encouraging $(1,2,5,6)$. Endoscopic clipping has been tried in our case as well, yet resulted with early failure. Several different surgical approaches have been developed to address this problem so far, however, the optimal strategy is still controversial. Direct closure of the tracheal and esophageal defects, segmental trachea resection and re-anostomosis with direct esophageal closure, closure of both defects with soft tissue flaps have all been employed (7-9). The disadvantage of these techniques is the remaining juxtaposed anastomosis line after separate closure of tracheal and esophageal sides. That being so, breakdown of one closure line increases the risk of failure on the other side and eventually increasing the chances of recurrence or persistence of the fistula (10). In order to overcome this problem Provenzano et al. used slide tracheoplasty technique for the first time, in the treatment of TEF. They performed slide tracheoplasty with periosteal support to nine children with congenital TEF without any recurrences. In contrast to other techniques, this method offsets the tracheal and esophageal anostmosis lines and prevent juxtaposition of the sides. In addition, the longer anastomosis line used in this technique distributes the tension to a greater surface area resulting in reduced anastomosis tension (8). In this case, we successfully adapted the same technique to an adult patient with congenital H-type TEF by using a hyoid muscle flap instead of periosteum for reinforcement.

\section{CONCLUSION}

In conclusion, we present our own experience with this novel technique and recommend this method for the treatment of TEF also in adult population since it is safe, well tolerated and considered to be associated with lower recurrence rate. 


\section{CONFLICT of INTEREST}

The authors reported no conflict of interest related to this article.

\section{AUTHORSHIP CONTRIBUTIONS}

Concept/Design: SU, UK, RD, RÖG

Analysis/Interpretation: SU, UK

Data Acquisition: SU, UK

Writing: SU, UK

Critical Revision: SU, UK, RD, RÖG

Final Approval: SU, UK, RD, RÖG

\section{REFERENCES}

1. Ke $M, W u X$, Zeng J. The treatment strategy for tracheoesophageal fistula. J Thorac Dis 2015; 7(Suppl 4): S38997.

2. Zacharias J, Genc O, Goldstraw P. Congenital tracheoesophageal fistulas presenting in adults: presentation of two cases and a synopsis of the literature. I Thorac Cardiovasc Surg 2004; 128(2): 316-8.

3. Mathey J, Lemoine A. Tracheal diverticulum and congenital oesophagotracheal fistula without oesophageal atresia. Thorax 1954; 9(2): 106-11.
4. Genty E, Attal P, Nicollas R, Roger G, Triglia JM, Garabedian $E N$, et al. Congenital tracheoesophageal fistula without esophageal atresia. Int I Pediatr Otorhinolaryngol 1999; 48(3): 231-8.

5. Azoulay D, Regnard JF, Magdeleinat P, Diamond T, RojasMiranda A, Levasseur P. Congenital respiratory-esophageal fistula in the adult. Report of nine cases and review of the literature. I Thorac Cardiovasc Surg 1992; 104(2): 381-4.

6. Hajjar W, Iftikhar A, Al Nassar S, Rahal S. Congenital tracheoesophageal fistula: $A$ rare and late presentation in adult patient. Ann Thorac Med 2012; 7(1): 48-50.

7. Mangi AA, Gaissert HA, Wright CD, Allan JS, Wain JC, Grillo HC, et al. Benign broncho-esophageal fistula in the adult. Ann Thorac Surg 2002; 73(3): 911-5.

8. Provenzano MJ, Rutter MJ, von Allmen D, Manning PB, Paul Boesch R, Putnam PE, et al. Slide tracheoplasty for the treatment of tracheoesophogeal fistulas. J Pediatr Surg 2014; 49(6): 910-4.

9. Shen KR, Allen MS, Cassivi SD, Nichols FC, Wigle DA, Harmsen WS, et al. Surgical management of acquired nonmalignant tracheoesophageal and bronchoesophageal fistulae. Ann Thorac Surg 2010; 90(3): 914-8; discussion 9.

10. Kovesi T, Rubin S. Long-term complications of congenital esophageal atresia and/or tracheoesophageal fistula. Chest 2004; 126(3): 915-25. 